\title{
Bone Marrow Transplantation Reproduces the Tristetraprolin-Deficiency Syndrome in Recombination Activating Gene-2 (-/-) Mice

\author{
Evidence That Monocyte/Macrophage Progenitors May Be Responsible for TNF $\alpha$ Overproduction
}

\author{
Ester Carballo, * Gary S. Gilkeson,‡ and Perry J. Blackshear* \\ *Howard Hughes Medical Institute Laboratory and the Section of Diabetes and Metabolism, Division of Endocrinology, Metabolism and \\ Nutrition, Department of Medicine and Department of Biochemistry, Duke University Medical Center, Durham, North Carolina 27710; \\ and ${ }^{\ddagger}$ Division of Rheumatology, Department of Medicine, Medical University of South Carolina, Charleston, South Carolina 29425
}

\begin{abstract}
Tristetraprolin-deficient [TTP $(-/-)]$ mice exhibit a complex syndrome of myeloid hyperplasia, cachexia, dermatitis, autoimmunity, and erosive arthritis. Virtually the entire syndrome can be prevented by the repeated injection of anti-TNF $\alpha$ antibodies (Taylor, G.A., E. Carballo, D.M. Lee, W.S. Lai, M.J. Thompson, D.D. Patel, D.I. Schenkman, G.S. Gilkeson, H.E. Broxmeyer, B.F. Haynes, and P.J. Blackshear. 1996. Immunity. 4:445-454). In the present study, we transplanted bone marrow from TTP $(-I-)$ and $(+I+)$ mice into recombination activating gene-2 $(-I-)$ mice. After a lag period of several months, marrow transplantation from the $(-I-)$ but not the $(+I+)$ mice resulted in the full syndrome associated with TTP deficiency, suggesting that hematopoietic progenitors are responsible for the development of the syndrome. Western blot analysis of supernatants from cultured TTP-deficient macrophages derived from the peritoneal cavity or bone marrow of adult TTP (-I-) mice, or from fetal liver, demonstrated an increased accumulation of TNF $\alpha$ after stimulation with LPS compared to control cells, and also increased accumulation of TNF $\alpha$ mRNA. This difference was not observed with cultured fibroblasts or $T$ and B lymphocytes. These data suggest that macrophages are among the cells responsible for the effective excess of $\mathrm{TNF} \alpha$ that leads to the pathology reported in TTP $(-I-)$ animals, and that macrophage progenitors may be involved in the transplantability of this syndrome. (J. Clin. Invest. 1997. 100:986-995.) Key words: arthritis - autoimmunity • extramedullary hematopoiesis • inflammation $\bullet$ myelopoiesis
\end{abstract}

\section{Introduction}

Tristetraprolin (TTP) $)^{1}$ (1), also known as TIS11 (2), Nup475 (3) or G0S24 (4), is a $\mathrm{Zn}^{2+}$-binding protein that is the product of the immediate-early response gene $Z f p-36$ (1-6). It contains

Address correspondence to Dr. P.J. Blackshear, National Institute of Environmental Health Sciences A2-05, 111 Alexander Drive, Research Triangle Park, NC 27709. Phone: 919-541-4899; FAX: 919-5414571; E-mail: Black009@niehs.nih.gov

Received for publication 28 March 1997 and accepted in revised form 24 June 1997.

J. Clin. Invest.

(C) The American Society for Clinical Investigation, Inc. 0021-9738/97/09/0986/10 \$2.00

Volume 100, Number 5, September 1997, 986-995

http://www.jci.org two zinc fingers of the unusual $\mathrm{CCCH}$ class, which recently have been shown to bind $\mathrm{Zn}^{2+}$ with high affinity $\left(K_{\mathrm{d}} \leq 10^{-11}\right)$ and represent a novel type of zinc finger structure (7). In fibroblasts, the protein appears to be localized to the cell nucleus in quiescent cells and is rapidly (within $5 \mathrm{~min}$ ) translocated from the nucleus to the cytoplasm upon stimulation with serum or other mitogens; this translocation is accompanied by increased serine phosphorylation of the protein $(8,9)$. The protein is widely distributed, and its expression is particularly high in spleen, lymph nodes, and thymus (1). The biological function of this protein is unknown, but existing data suggest that it may be a transcription factor.

Gene disruption in mice has proven to be a useful method by which to evaluate proteins of unknown function. We recently generated TTP-deficient [TTP $(-/-)]$ mice; these animals exhibited a complex syndrome consisting of cachexia, alopecia, dermatitis, conjunctivitis, erosive arthritis, myeloid hyperplasia, glomerular mesangial thickening, and high titers of antinuclear and anti-DNA antibodies (10). This phenotype displayed aspects that resemble several human diseases, including rheumatoid arthritis (11), systemic lupus erythematosus (12), and agnogenic myeloid metaplasia (13). There is strong evidence to suggest that the two former diseases have an autoimmune component (14); although the etiology of agnogenic myeloid metaplasia remains unknown, the presence of autoantibodies in these patients has also been reported (13).

Because the TTP $(-/-)$ mice resembled mouse models of TNF $\alpha$ excess (15-17), we treated newborn TTP $(-/-)$ mice with repeated injections of a specific $\mathrm{mAb}$ to mouse $\mathrm{TNF} \alpha$ (18). This treatment completely prevented the development of all known aspects of the TTP-deficiency phenotype (10). In addition, antibody withdrawal resulted in the rapid development of TTP-deficiency syndrome (our unpublished data). These studies implicated TTP in the production, clearance, or action of TNF $\alpha$, in that TTP deficiency in some way appeared to produce a chronic state of effective TNF $\alpha$ excess. However, the mechanism by which TTP deficiency results in this effective $\mathrm{TNF} \alpha$ excess, and the cellular source(s) of $\mathrm{TNF} \alpha$, remain unknown.

To begin to explore the cellular sources of TNF $\alpha$ in TTP $(-/-)$ mice, we wished first to determine whether TNF $\alpha$ emanated directly or indirectly from cells derived from bone marrow. In this study, we transplanted marrow from TTP $(-/-)$ mice and their control $(+/+)$ littermates into recombination activating gene (RAG)-2-deficient [RAG-2 (-/-)] mice. Disruption of either the RAG-1 or -2 genes leads to the arrest of $\mathrm{T}$ and $\mathrm{B}$ lymphocyte development in the $\mathrm{CD}^{-} / \mathrm{CD}^{-}$thymocyte

1. Abbreviations used in this paper: GAPDH, glyceraldehyde-3-phosphate dehydrogenase; M-CSF, macrophage colony-stimulating factor; RAG, recombination activating gene; TTP, tristetraprolin. 
or the $\mathrm{B} 220^{+} / \mathrm{CD} 43^{+}$pro-B cell $(19,20)$. This leads to a severe combined immune-deficient phenotype, similar to that observed in severe combined immune deficient mice (21). RAG-2 $(-/-)$ mice do not show any hematological alterations other than lack of mature lymphocytes; the development of the rest of the hematopoietic system appears to be normal (20).

Our studies revealed that essentially all aspects of TTPdeficiency syndrome could be induced in RAG-2 (-/-) mice transplanted with marrow from TTP $(-/-)$ mice. The syndrome developed after a lag period of several months, long after the early reconstitution of lymphocyte populations in the recipients. Analysis of individual cell types from TTP (-/-) mice indicated that macrophages but not lymphocytes overexpressed TNF $\alpha$, both in the basal state and in response to stimuli such as LPS. These studies suggest that macrophage progenitors are among the transplanted cells capable of reconstituting the TTP-deficiency phenotype in RAG-2 (-/-) mice. They also raise the possibility that macrophages are among the sources of the presumed TNF $\alpha$ overproduction in TTP $(-/-)$ animals.

\section{Methods}

Mice. TTP $(-/-)$ mice were generated in our laboratory as previously described (10). Genotyping of offspring was performed by Southern blot analysis of tail DNA as described (22), using as a probe an SstII/SstI 1.1-kb fragment of the genomic DNA (23). RAG-2 (-/-) mice were obtained from a colony maintained at the Division of Laboratory Animal Resources, Duke University Medical Center (Durham, NC). All mice were maintained in autoclaved microisolator cages in a barrier facility, and fed with autoclaved food and acidified water.

Bone marrow transplantation. Bone marrow from two male TTP $(-/-)$ mice and their two male TTP $(+/+)$ littermates (age $6 \mathrm{mo}$ ) was obtained as described (24). $10^{7}$ total bone marrow cells in a final volume of $300 \mu \mathrm{l}$ were injected intravenously through the tail vein into 10 RAG-2 (-/-) female mice (7-9 wk old), 5 receiving marrow from TTP $(-/-)$ mice $[(-/-)$ recipient group], and 5 receiving marrow from TTP $(+/+)$ mice $[(+/+)$ recipient group]. Two groups were established, one of six mice receiving marrow from one pair of $(-/-)$ and $(+/+)$ mice, and another of four mice receiving marrow from the other pair of mice. Mouse body weight was assessed weekly after the transplantation, and blood smears (tail bleeding) were performed monthly. One mouse each from the $(-/-)$ and $(+/+)$ recipient groups was analyzed $10 \mathrm{wk}$ after the transplantation. The remaining animals were analyzed at later time points, usually when the recipients of the ( $-/-)$ marrow were near death. Animals were killed by $\mathrm{CO}_{2}$ inhalation, and careful autopsies were performed. When possible, blood was collected into heparinized tubes for cell counts. Nonanticoagulated venous blood (vena cava) was collected for blood smears and for serum. Blood smears were stained using the modified Wright stain Diff Quik Stain Set (Baxter Healthcare Corp., McGaw Park, IL). Tissues for histology were processed, stained, and photographed as described (10). Bone marrow was flushed from the femurs with RPMI $/ 10 \%$ (vol/vol) FCS. Cells were deposited onto glass slides (cytopreps) using a cytocentrifuge (Shandon Inc., Pittsburgh, PA), and imprints from spleen, lymph nodes, and liver were stained with the Diff Quik Stain Set.

In situ hybridization histochemistry for presence of the $Y$ chromosome. Tissue samples for DNA in situ hybridization were processed as described (25). Bone marrow cytopreps were fixed in ice-cold etha$\mathrm{nol} / \mathrm{acetic}$ acid (3:1) (vol/vol), and kept at $-20^{\circ} \mathrm{C}$ until used. In situ hybridization histochemistry was performed as described (25) using a mouse Y chromosome probe (26), kindly provided by Dr. Colin E. Bishop (Baylor College of Medicine, Houston, TX). The probe was labeled with digoxigenin with the DNA Labeling and Non-Radioactive Detection Kit (Boehringer Mannheim Biochemicals, Indianapolis, IN), following the instructions of the manufacturer.

Detection of autoantibodies. Detection of anti-DNA and antinuclear antibodies was performed as described previously (10).

Culture of peritoneal macrophages. To investigate possible cellular sources of excess TNF $\alpha$ in TTP (-/-) mice, peritoneal macrophages were prepared from two TTP $(-/-)$ mice $(10)$ and their two TTP $(+/+)$ littermates at 3 mo of age as described (27). Purity of the macrophage population was assessed by Giemsa stain and nonspecific esterase activity (28). Macrophages were plated at $2.5 \times 10^{5}$ cells/well in 96-well plates, in DMEM supplemented with 10\% (vol/ vol) FCS, and cultured for $24 \mathrm{~h}$ in the presence of different concentrations of LPS (Sigma Chemical Co., St. Louis, MO). The supernatants were then assayed for TNF $\alpha$ accumulation as described below.

Culture of fetal liver macrophages. Fetal liver macrophages were obtained from hematopoietic progenitors present in fetal liver according to the method described by Warren and Vogel (29) for bone marrow-derived macrophages. Pregnant TTP $(+/-)$ females that had been mated with TTP $(+/-)$ males were killed by $\mathrm{CO}_{2}$ inhalation on days $14-16$ of gestation, and the fetuses were removed. Single cell suspensions from the livers were cultured for $2 \mathrm{wk}$ in MEM (GIBCO BRL, Gaithersburg, MD) supplemented with $10 \%$ (vol/vol) FCS, 15 $\mathrm{mM}$ Hepes ( $\mathrm{pH} 7.4$ ), 0.2\% (wt/vol) sodium bicarbonate, $100 \mathrm{U} / \mathrm{ml}$ penicillin, $100 \mu \mathrm{g} / \mathrm{ml}$ streptomycin $(\mathrm{P} / \mathrm{S}), 2 \mathrm{mM}$ glutamine, and $30 \%$ LM/TK ${ }^{-}$cell (American Type Culture Collection, Rockville, MD)conditioned medium, prepared as described (30). After 2 wk in culture, cells were harvested with the neutral protease Dispase II (Boehringer Mannheim Biochemicals) $\left(1.5 \mathrm{mg} / \mathrm{ml}\right.$ in $\mathrm{Ca}^{2+} / \mathrm{Mg}^{2+}$-free Earle's balanced salt solution) as described (29), except that the cells were resuspended in RPMI supplemented with $2 \mathrm{mM}$ glutamine, $\mathrm{P} / \mathrm{S}, 30 \mathrm{mM}$ Hepes (pH 7.4), and $0.4 \%$ (wt/vol) sodium bicarbonate, using $10 \%$ ( $\mathrm{vol} / \mathrm{vol}$ ) instead of $2 \%$ FCS (wash medium). Purity of the preparations was assessed by morphology (Diff Quik Stain Set) and nonspecific esterase activity. By these criteria, the cells obtained by this method were $>90 \%$ macrophages. Macrophages were then plated at $1.25 \times 10^{6}$ cells $/ \mathrm{ml}$ on $96-$ well plates and incubated in $200 \mu \mathrm{l}$ of the same medium at $37^{\circ} \mathrm{C}$ for $24 \mathrm{~h}$ before being stimulated for another $24 \mathrm{~h}$ with increasing concentrations of LPS. In another series of studies, cells were plated in 60-mm dishes, and incubated in the presence or absence of $1 \mu \mathrm{g} / \mathrm{ml}$ LPS for $4 \mathrm{~h}$. In all cases, supernatants were harvested and assayed for TNF $\alpha$ accumulation by Western blot, as described below. Cells from the 4-h LPS stimulation were harvested and used for measurement of TNF $\alpha$ and glyceraldehyde-3-phosphate dehydrogenase (GAPDH) mRNA levels, as described below.

Culture of bone marrow-derived macrophages. Bone marrowderived macrophages were prepared as described by Warren and Vogel (29) from five TTP $(-/-)$ and five TTP $(+/+)$ mice (age 6-7 mo). Cells were cultured as described above for fetal liver macrophages, except that at day 1, cells were split in two $T 75 \mathrm{~cm}^{2}$ flasks (Becton Dickinson Labware, Franklin Lakes, NJ), and were cultured for only $10 \mathrm{~d}$. At that point, they appeared to be essentially $100 \%$ macrophages, as determined by morphology and nonspecific esterase staining. On day 10, the cells were rinsed once with wash medium and incubated in the same medium for $24 \mathrm{~h}$. At that point, the medium was removed and replaced by fresh medium after one wash, and the cells were incubated in the presence or absence of $1 \mu \mathrm{g} / \mathrm{ml}$ LPS for $4 \mathrm{~h}$. The supernatants were then harvested and assayed for TNF $\alpha$ accumulation by Western blot, as described below; the cells were harvested and used for the measurement of TNF $\alpha$ and GAPDH mRNA levels, as described below.

Preparation of $B$ and T lymphocytes. B and T lymphocytes were prepared from thymus $(31)$ and spleen $(32,33)$ of 11 -d-old TTP $(+/+)$ and $(-/-)$ littermate mice, and cultured at $10^{6}$ cells $/ \mathrm{ml}$ in RPMI $/ 10 \%$ FCS, in the presence of recombinant murine IL-2 (R \& D Systems, Inc., Minneapolis, MN), PHA (Sigma Chemical Co.), or LPS for $24 \mathrm{~h}$, and supernatants were harvested to measure the accumulation of TNF $\alpha$ by Western blot, as described below. 
Western blotting. Volumes of supernatant corresponding to $1.25 \times$ $10^{5}$ cells were mixed with $1 / 5$ volume of $5 \times$ SDS sample buffer (34), boiled for $5 \mathrm{~min}$, then loaded onto $16 \%$ SDS-polyacrylamide gels (Protogel; National Diagnostics, Atlanta, GA) and subjected to electrophoresis at $40 \mathrm{~V}$ for $16 \mathrm{~h}$. Western blotting was performed by standard techniques, in which a rabbit anti-mouse TNF $\alpha$ antiserum [(35), kindly provided by Dr. Fred Kull (GlaxoWellcome Inc., Research Triangle Park, NC)] at 1:2,500 in Tris-buffered saline $/ 0.5 \%$ Tween 20 (TBS/T) was incubated with the membranes for $1 \mathrm{~h}$ at room temperature. The blots were incubated with secondary antibody (goat antirabbit, horseradish peroxidase-conjugated; Bio-Rad Labs., Hercules, $\mathrm{CA}$ ) at a 1:5,000 dilution in TBS/T for $30 \mathrm{~min}$ at room temperature. Membranes were developed with the Amersham Corp. ECL Detection System (Arlington Heights, IL) as recommended by the manufacturer, and scanned using a Zeineh Soft Laser Scanning Densitometer (model SL-504-XL; Biomed Instruments Inc., Fullerton, CA).

Northern blotting. Total cellular RNA was obtained from marrow macrophage cultures and fetal liver-derived macrophage cultures using Tri Reagent (Molecular Research Center, Inc., Cincinnati, $\mathrm{OH}$ ), according to the method described by Chomczynski (36). Genomic DNA was isolated from the same samples and used to estimate the number of cells present in each sample. $10 \mu \mathrm{g}$ RNA from the bone marrow-derived macrophages and $3.8 \mu \mathrm{g}$ from the fetal liver-derived macrophages were separated on $1.2 \%$ agarose/formaldehyde gels and processed for Northern blotting as described (22). The filters were probed successively with a mouse cDNA for TNF $\alpha$ (American Type Culture Collection) and a rat cDNA for GAPDH
(37). PhosphorImager analysis was used for quantitation of the blots; the results were expressed as quotients of TNF $\alpha$ mRNA $\div$ GAPDH mRNA from each animal, and these quotients were then averaged and compared using Student's $t$ test.

\section{Results}

RAG-2 (-/-) female mice at 7-9 wk of age received bone marrow from either TTP $(-/-)$ or $(+/+)$ male mice. None of the recipient mice showed any acute adverse effects within 1 mo of transplantation that could suggest graft versus host disease. Engraftment was assessed by the appearance of mature lymphocytes in peripheral blood, which occurred within $1 \mathrm{mo}$ of transplantation in all 10 recipients of either TTP $(-/-)$ or $(+/+)$ bone marrow (data not shown). At various times during the study, recipient animals were killed and analyzed pathologically; at each point, a $(-/-)$ marrow recipient was compared to a $(+/+)$ marrow recipient.

Body weight. Loss of weight or failure to gain weight normally is one of the most prominent aspects of the TTP-deficiency phenotype (10). No evident differences in the growth curves of the $(+/+)$ and $(-/-)$ recipients were apparent for the first 3 mo after transplantation (Fig. 1). However, three of the five recipients of $(-/-)$ marrow then exhibited varying degrees of weight loss, ranging from profound (mouse 8) to mod-

A

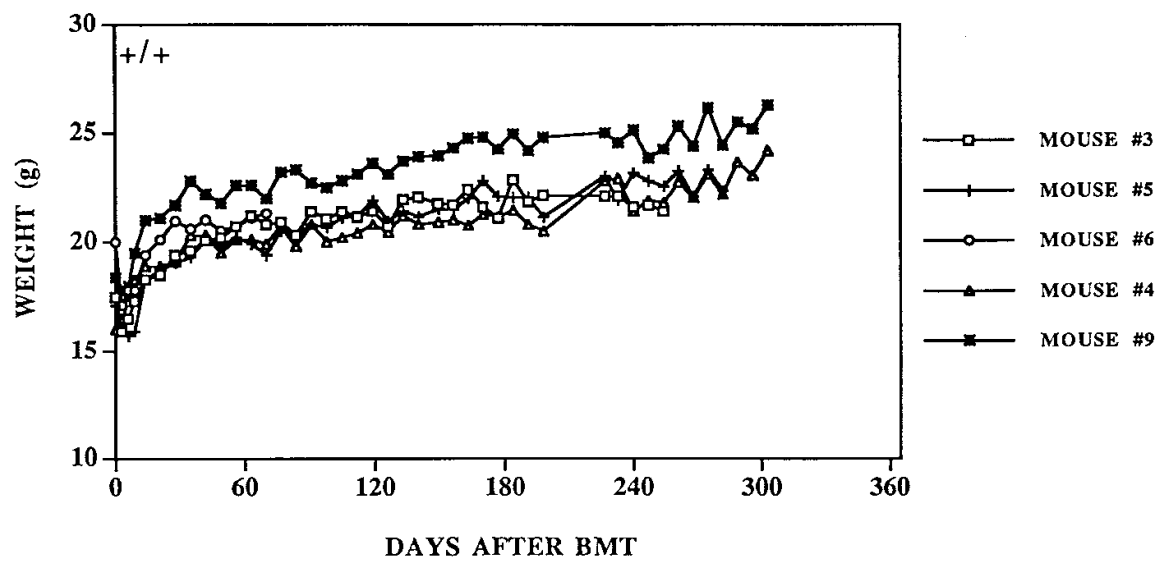

B

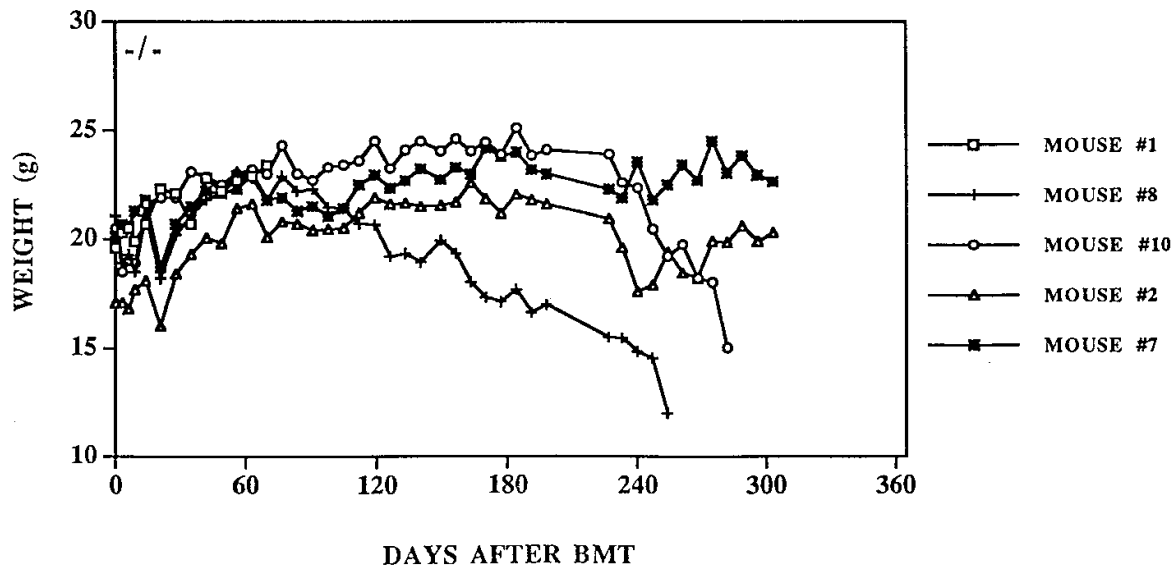

Figure 1. Growth curves of RAG-2 (-/-) mice receiving bone marrow from TTP $(+/+)(A)$ or $(-/-)(B)$ mice. None of the $(+/+)$ recipients exhibited growth arrest or weight loss during the 10 mo of the study. In contrast, even though none of the $(-/-)$ recipients showed any growth retardation during the first 3 mo of the study, after that period one of them (mouse 8) exhibited clear weight loss. Mice 2 and 10 also showed a similar pattern of weight loss after $6.5 \mathrm{mo}$, although mouse 2 recovered somewhat by the end of the study. Mouse 7 never exhibited clear weight loss. $B M T$, bone marrow transplantation. 
erate (mice 10 and 2 ; Fig. $1 B$ ). Of the recipients of $(-/-$ ) marrow, mouse 1 was selected randomly for pathological evaluation at $10 \mathrm{wk}$ after transplantation, before any of the animals showed evidence of weight loss, and mouse 7 never exhibited weight loss, despite repeated detection of circulating lymphocytes. None of the five recipients of $(+/+)$ marrow exhibited weight loss or clinical or pathological abnormalities (Fig. $1 A$ ).

The weight loss was accompanied by nearly complete absence of adipose tissue in any of the usual fat depots (subcutaneous, mesenteric, perirenal) in three out of five of the mice receiving ( $-/-$ ) marrow (see below). Even mouse 1, randomly selected for pathological examination $10 \mathrm{wk}$ after transplantation, exhibited less adipose tissue than its control (not shown). Mouse 7 was the only recipient of TTP $(-/-)$ marrow that appeared to have normal amounts of fat (not shown).

Histology. Histological evaluation of the recipients of $(-/-)$ marrow revealed evidence of both medullary and extramedullary myeloid hyperplasia, as described previously for TTPdeficient mice (10). The bone marrow from all of the $(-/-)$ recipient mice appeared grossly white, in contrast to the red marrow from $(+/+)$ recipients; this difference was observed consistently in our previous study of TTP $(-/-)$ and $(+/+)$ mice (10). Marrow from all of the $(-/-)$ recipients exhibited an increase in myeloid cells compared to $(+/+)$ recipients $[73.8 \pm 11.5 \%$ myeloid cells in $(-/-)$ recipients $(n=5)$ vs. $47.2 \pm 8 \%$ myeloid cells in $(+/+)$ recipients (mean $\pm \mathrm{SD}, n=5)$, $P=0.007$; see Fig. 2, $A$ and $B]$.

Peripheral blood white cell counts were increased only in mouse $2\left[98 \times 10^{3} / \mu\right.$ l compared to the control range of $5.7 \pm$ $\left.2.1 \times 10^{3} / \mu \mathrm{l}(n=2)\right]$. Peripheral blood smears from this mouse showed an increase in circulating myeloid cells, both from the granulocytic and monocytic lineages [77.3\% myeloid cells (monocytes + granulocytes) in mouse 2, vs. $52 \%$ myeloid cells in the age-matched controls].

Livers from $(-/-)$ recipient mice appeared grossly normal at autopsy in four out of five animals. However, mouse 2 exhibited significant enlargement of the liver [1.8 g, compared to $1.2 \pm 0.3 \mathrm{~g}(n=2)$ in the age-matched controls]. Multiple white nodules were apparent on the surface of the organ; these consisted largely of granulocytes, which also infiltrated the rest of the hepatic parenchyma (not shown). Imprints from these nodules confirmed the presence of myeloid cells at different stages of differentiation. The liver from mouse 7 also contained foci of granulocytes, with massive granulocytic infiltration of the gall bladder wall (not shown). Abnormal foci of granulocytes were not detected in the livers of the other three $(-/-)$ recipients, or in the livers of any of the $(+/+)$ recipients.

Splenomegaly was not generally present in $(-/-)$ recipient mice, except for mouse 2, whose spleen weighed $374 \mathrm{mg}$ (compared to $90.5 \pm 2.8 \mathrm{mg}$ in age-matched controls, $n=2$ ). However, all $(-/-)$ recipients exhibited infiltration of the spleen with myeloid cells. They also contained increased numbers of megakaryocytes compared to $(+/+)$ recipient spleens. Imprints of the spleens from $(-/-)$ recipients revealed myeloid cells in all stages of differentiation (Fig. $2 C$ and $D)$. In $(-/-)$ recipients, the increase in the number of myeloid cells was accompanied by destruction of the normal architecture of the
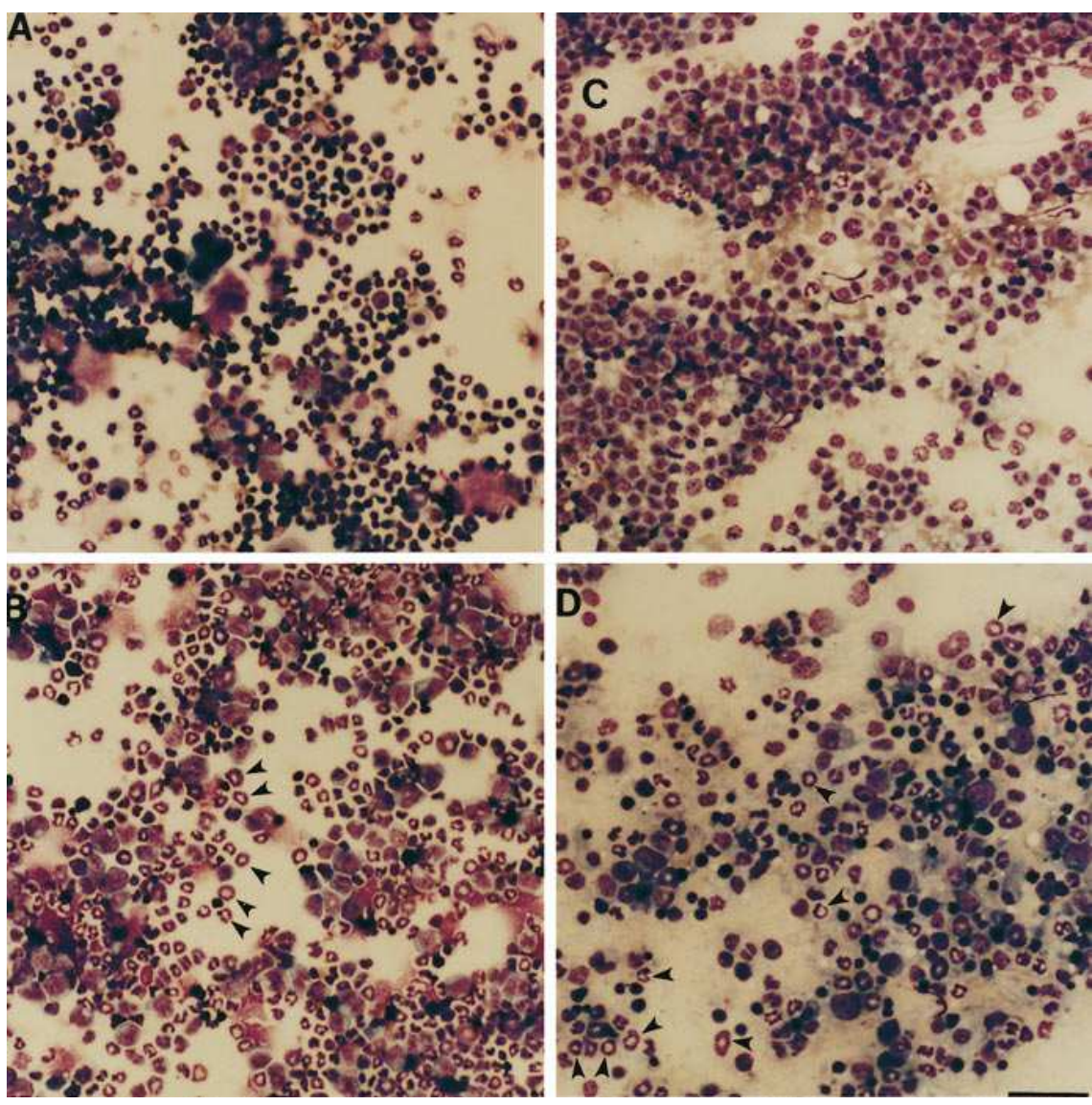

Figure 2. Bone marrow and spleen cells from $(-/-)$ and $(+/+)$ marrow recipients. Bone marrow cells were flushed out of the femurs, washed in culture medium, and centrifuged onto glass slides. Spleen sections were used to perform imprints. All cells were stained with the Diff Quik Stain Set. $(A)$ Bone marrow from a $(+/+)$ marrow recipient. $(B)$ Bone marrow from one of the $(-/-)$ marrow recipients. Note the increased percentage of mature granulocytes (arrowheads), and the virtually complete absence of mature erythrocytes or erythroid precursors, compared to the marrow in $A$. $(C)$ Imprint from the spleen of a mouse receiving TTP $(+/+)$ marrow, composed mainly of lymphocytes. $(D)$ Imprint from the spleen of a $(-/-)$ marrow recipient. In this preparation, it is easy to identify the presence of myeloid cells in different stages of differentiation (arrowheads), and the lower percentage of lymphocytes compared to $C$. Bar $=0.05 \mathrm{~mm}$. 
spleen, without clear distinction between the white and red pulp (not shown).

Mouse $2[(-/-)$ recipient $]$ also exhibited lymphadenopathy, in which myeloid cells were also present (not shown).

The skin from $(+/+)$ recipients appeared normal (Fig. 3 $A)$. In three out of five $(-/-)$ recipient mice, the skin completely lacked subcutaneous fat, as seen in TTP $(-/-)$ mice (10) (Fig. 3 B). Some animals exhibited a perivascular inflammatory infiltrate in the dermis (Fig. $3 B$ ).

The carpal joints from $(-/-)$ recipient mice showed varying extents of inflammatory pannus, bone erosion, and bone destruction (Fig. $3 \mathrm{D}$ ). As in TTP-deficient mice (10), there was generalized enlargement of the marrow cavities in all of the $(-/-)$ recipients, which were full of active hematopoietic cells, particularly of the myeloid lineage (Fig. $3 \mathrm{D}$ ). In contrast, $(+/+)$ recipients exhibited mostly fat and very few hematopoietic cells in the marrow (Fig. 3 C). Neither mouse 1, which was analyzed only $10 \mathrm{wk}$ after marrow transplantation, nor mouse 7 , which appeared to be healthy after $10 \mathrm{mo}$ of follow-up, exhibited an inflammatory pannus in the carpal joints (not shown). However, mice 2, 8, and 10 exhibited varying amounts of inflammatory pannus that completely destroyed the bone surface and articular cartilage and infiltrated the marrow cavities (Fig. $3 \mathrm{D}$ ).

Autoantibodies. 4 mo after marrow transplantation, only mouse 2 exhibited antinuclear antibodies and anti-DNA antibodies, both by ELISA and the Crithidia assay. However, by the end of the study, all three $(-/-)$ recipients studied were positive for antibodies to both single- and double-stranded DNA [for single-stranded DNA, the mean \pm SD of ELISA units from the three $(-/-)$ recipient mice was $0.52 \pm 0.42 \mathrm{com}$ pared with $0.014 \pm 0.005$ for the two $(+/+)$ recipients; for double-stranded DNA, the values were $0.5 \pm 0.37$ for $(-/-)$ recipients vs. $0.034 \pm 0.026$ for $(+/+)$ recipients]. Antinuclear antibodies were positive in mouse 2 , but negative in the other two $(-/-)$ recipients and in both of the $(+/+)$ recipients studied.

In situ hybridization for $Y$ chromosome. In situ hybridization with a DNA probe for mouse chromosome $Y$ was performed in an attempt to establish the origin of the myeloid cells present in the transplanted animals. In bone marrow, there was a mixed population of myeloid cells positive for the Y chromosome (from the donor) and cells that were negative
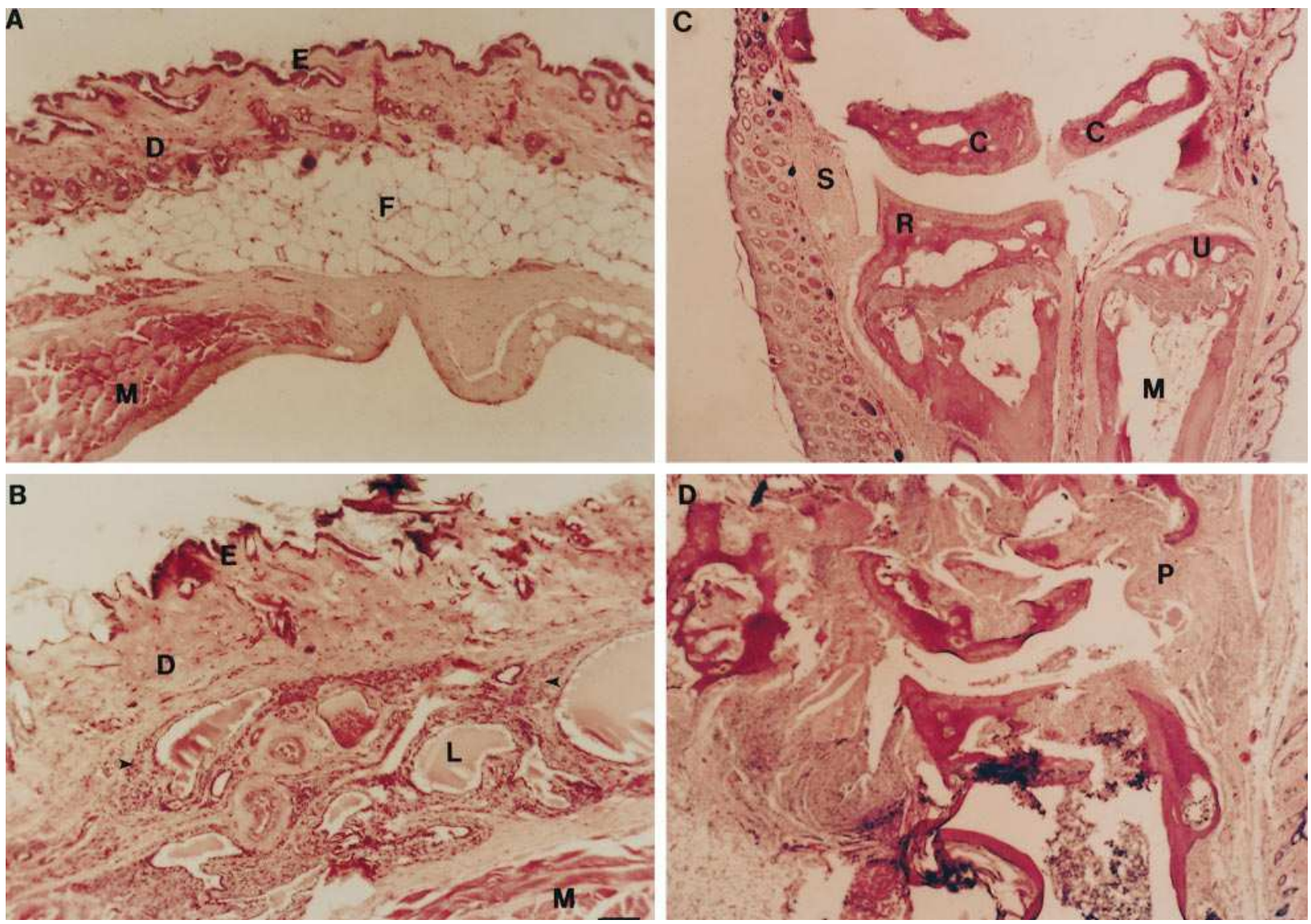

Figure 3. Histology of the skin and carpal joint in $(-/-)$ and $(+/+)$ marrow recipients. $(A)$ Section of skin from a $(+/+)$ marrow recipient, showing the normal architecture of epidermis $(E)$, dermis $(D)$, and the thick layer of subcutaneous fat $(F)$. $(B)$. Section of skin from a $(-/-)$ marrow recipient mouse. Note the total absence of subcutaneous fat, as well as the inflammatory reaction in the dermis (arrowheads), and an extremely dilated lymphatic vessel $(L) . M$, muscle. Hematoxylin-eosin. Bar $=0.1 \mathrm{~mm}$ for $A$ and $B .(C)$ Section of the carpal joint $(C$, carpal bones), and the distal portion of the ulna $(U)$ and radius $(R)$ in a $(+/+)$ marrow recipient. Note the absence of hematopoietic cells in the marrow cavity $(M)$, which appears relatively empty. Note also the smooth articular surfaces in the carpal joints, and the normal synovium $(S)$. $(D)$ Equivalent section to that shown in $C$, but from a $(-/-)$ marrow recipient. Note that the marrow cavity appears full of hematopoietic cells. Note the thinness of the articular bone, compared with panel $C$. Note also the destruction of the articular cartilage and bone by an invasive pannus $(P)$, as well as erosion of the radial head. Hematoxylin-eosin. Bar $=1 \mathrm{~mm}$ for $C$ and $D$. 

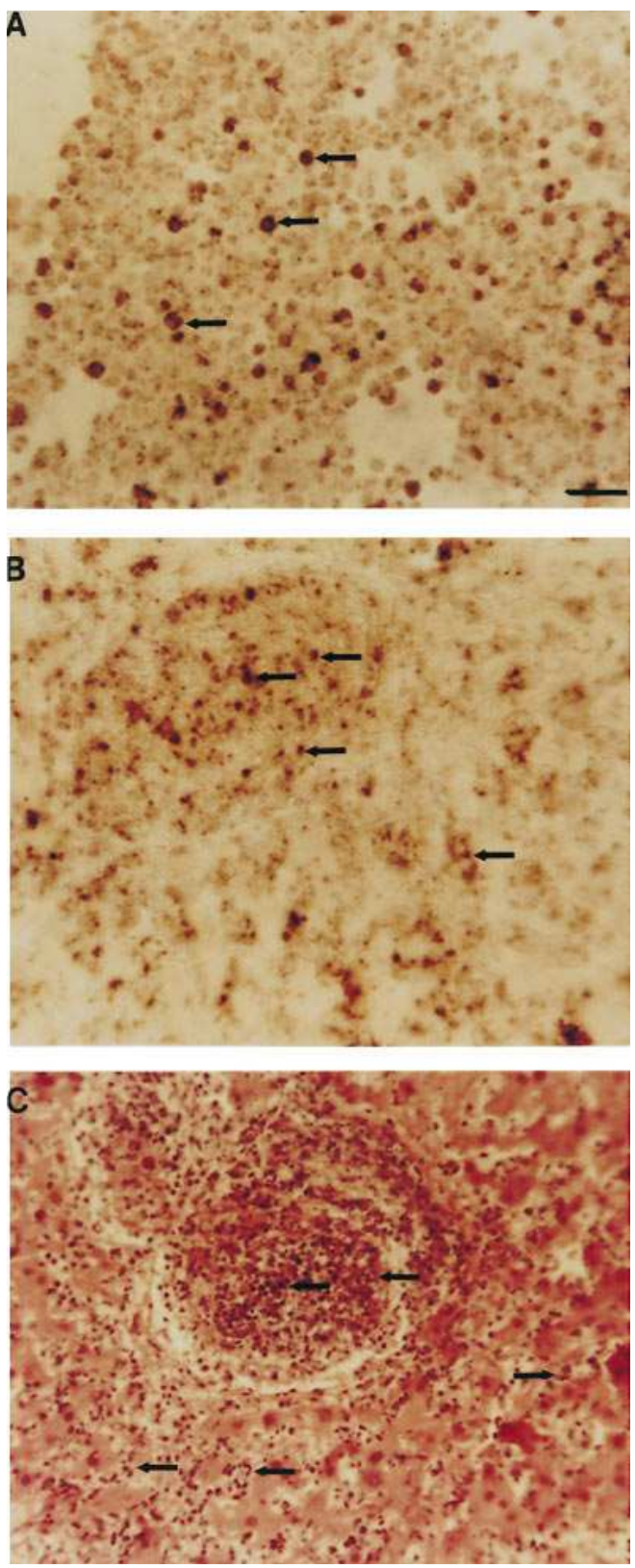

Figure 4. In situ hybridization with a Y chromosome probe. (A) In situ hybridization of bone marrow cells from a $(-/-)$ recipient, using a Y chromosome probe labeled with digoxygenin. Note the presence of positive cells from all cell lineages (arrows), but also negative cells, suggesting that the marrow population was a mixture of cells from donor and recipient. $(B)$ In situ hybridization with a Y chromosome probe in the liver of mouse $2(-/-)$. Note the presence of positive cells (arrows) derived from the donor, and the negative hepatocytes (from the recipient). (C) Hematoxylin-eosin staining of an equivalent section of liver to that shown in $B$. Note that the number of granulocytes (arrows) is greater than the number of positive cells detected by in situ hybridization, suggesting that only a fraction of the granulocytic cells infiltrating the liver was derived from the donor. $\mathrm{Bar}=0.05$ $\mathrm{mm}$ for $\mathrm{A}-\mathrm{C}$.

(from the recipient) in both $(-/-)$ and $(+/+)$ marrow recipients (Fig. $4 A$ ). In mouse 2, in situ hybridization was also performed on sections of spleen, lymph nodes, and liver. Virtually the entire spleen and lymph nodes showed an intense hybrid- ization signal, mainly due to the presence of mature lymphocytes originating from the donor (not shown). In the liver, only granulocytes and myeloid cells were positive for the $\mathrm{Y}$ chromosome, whereas the hepatocytes (recipient) were completely negative (Fig. 4 B). However, the number of Y chromosomepositive granulocytes in the liver represented only $\sim 50 \%$ of the total granulocytes present, as determined by hematoxylineosin staining (Fig. $4 C$ ).

$T N F \alpha$ production. Western blot studies were performed on supernatants from cultured macrophages and B and T lymphocytes in order to assess the production of TNF $\alpha$ by these cells. Three different sources of macrophages were used: resident peritoneal macrophages, obtained by lavage of the peritoneal cavity of adult mice; fetal liver-derived macrophages, obtained by culturing the hematopoietic precursors present in the fetal liver between days 14-16 of gestation; and bone marrowderived macrophages, obtained by culturing the hematopoietic precursors from the bone marrow of adult mice.

In all three cases, macrophages obtained from TTP (-/-) animals showed an increased accumulation of TNF $\alpha$ in the medium when stimulated with LPS. Thus, peritoneal macrophages from TTP $(-/-)$ mice, incubated for $24 \mathrm{~h}$ in the presence of $10 \mathrm{ng} / \mathrm{ml}$ of LPS, secreted readily detectable amounts of TNF $\alpha$ into the culture medium (data not shown). By contrast, under the same conditions, peritoneal macrophages from TTP $(+/+)$ mice did not produce detectable amounts of TNF $\alpha$ under our Western blot conditions. In these mice, measurable $\mathrm{TNF} \alpha$ accumulation occurred only after $24 \mathrm{~h}$ of incubation in the presence of $100 \mathrm{ng} / \mathrm{ml}$ LPS, and even then, the levels of $\mathrm{TNF} \alpha$ were much lower than those observed for the macrophages from TTP $(-/-)$ mice (not shown). Densitometry of the autoradiographs indicated that there was a 5.6-fold increase in the levels of TNF $\alpha$ present in the supernatants from the TTP $(-/-)$ peritoneal macrophages compared to the TTP $(+/+)$ cells exposed to $100 \mathrm{ng} / \mathrm{ml}$ LPS (not shown).

Macrophages derived from fetal liver exhibited essentially the same behavior. TNF $\alpha$ was readily detectable in the culture supernatants after $24 \mathrm{~h}$ in the presence of $1 \mathrm{ng} / \mathrm{ml} \mathrm{LPS}$, but at much higher levels in the $(-/-)$ than in the $(+/+)$ macrophages (Fig. $5 A$ ). These autoradiographs were analyzed by densitometry, and the results compared using Student's $t$ test. Fig. $5 B$ shows that at all LPS concentrations studied, there was about a fivefold greater accumulation of TNF $\alpha$ in the supernatants from $(-/-)$ cells compared to $(+/+)$ cells; these differences were statistically significant $(P<0.05)$. Longer exposure of these blots showed that, even in the absence of LPS, there was greater $\mathrm{TNF} \alpha$ accumulation in the supernatants from $(-/-)$ cells compared to $(+/+)$ cells (not shown).

Bone marrow-derived macrophages were exposed to $1 \mu \mathrm{g} /$ $\mathrm{ml}$ LPS for $4 \mathrm{~h}$, and the levels of TNF $\alpha$ present in the culture supernatants were assayed by Western blot. In all cases, the media from $(-/-)$ macrophages contained much higher levels of TNF $\alpha$ than the media from $(+/+)$ cells (Fig. 6 B). Densitometry of these autoradiographs revealed that there was a sevenfold greater accumulation of TNF $\alpha$ in the supernatants from $(-/-)$ cells compared to $(+/+)$ cells (Fig. $7 B$ ); this difference was statistically significant $(P<0.01)$.

Analysis of $\mathrm{TNF} \alpha$ production by $\mathrm{B}$ and $\mathrm{T}$ lymphocytes obtained from TTP $(-/-)$ and $(+/+)$ mice did not reveal any significant differences between cells of the two genotypes (not shown).

$\mathrm{TNF} \alpha$ mRNA levels were studied in fetal liver-derived 

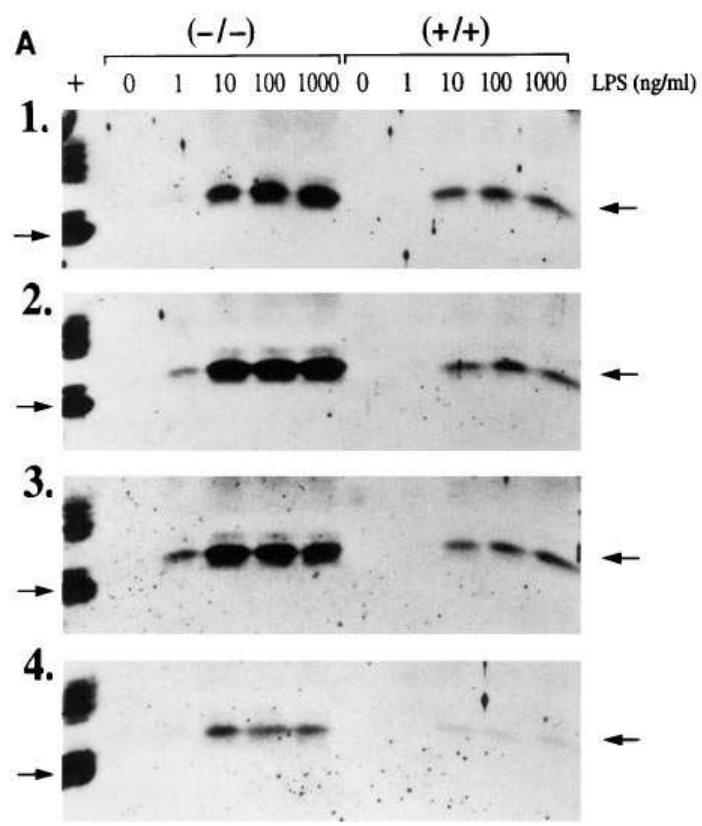

B

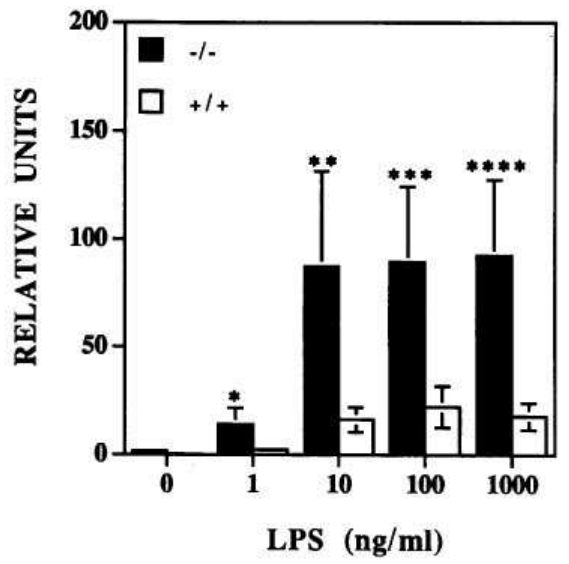

Figure 5. TNF $\alpha$ accumulation in the medium from TTP $(+/+)$ and $(-/-)$ macrophages. $(A)$ Macrophages derived from fetal liver precursors were prepared from four $(+/+)$ and four $(-/-)$ littermate mice, as described in Methods, and the supernatants were analyzed for the presence of TNF $\alpha$ after $24 \mathrm{~h}$ in culture. Each portion of the figure (1-4) represents results from a pair of $(-l-)$ and $(+/+)$ littermate embryos. Arrows indicate the position of mature, secreted TNF $\alpha$. The lane marked + indicates the positive control used in Western blot, i.e., TNF $\alpha$ present in the supernatant of LPS-stimulated RAW 264.7 cells. Note the greater accumulation of $\mathrm{TNF} \alpha$ in the supernatants from $(-/-)$ cells at all LPS concen-

trations relative to $(+/+)$ cells. $(B)$ Histogram of average values derived from densitometry of the blots shown in $A$, \pm SD. The mean values were compared by Student's $t$ test for paired comparisons; the differences between the means from the $(-/-)$ and $(+/+)$ macrophages were statistically significant at all LPS concentrations studied $(P<0.05) . * P=0.049$. ** $P=0.02 . * * * P=0.019$. **** $P=0.025$.

macrophages and in bone marrow-derived macrophages. In bone marrow-derived macrophages, the basal levels of TNF $\alpha$ mRNA were similar in $(-/-)$ and $(+/+)$ cells when normalized for GAPDH mRNA levels (Fig. 6 A and Fig. 7 A). However, after LPS stimulation $(1 \mu \mathrm{g} / \mathrm{ml}$ for $4 \mathrm{~h})$, the $\mathrm{TNF} \alpha$ mRNA levels in $(-/-)$ cells were approximately twice as great as those from $(+/+)$ cells $(P<0.05)$ (Fig. $6 A$ and Fig. $7 A)$. A similar twofold difference was observed in the fetal liverderived macrophages (not shown).

\section{Discussion}

The principal finding of this study was that transplantation of bone marrow from TTP $(-/-)$ mice into RAG-2 (-/-) mice resulted in the development of clinical and/or pathological aspects of the TTP-deficiency syndrome in $100 \%$ of the recipients. In contrast, none of the recipients of marrow from TTP $(+/+)$ littermates developed any aspect of the syndrome. These data clearly show that all of the known aspects of the TTP-deficiency syndrome can be transferred to RAG-2 (-/-) recipients by whole bone marrow transplantation.

In our previous report on these mice (10), we demonstrated that all known clinical and pathological aspects of the syndrome could be prevented by repeated intraperitoneal injections of an mAb specific for mouse TNFa (18). In more recent work, we have found that antibody withdrawal leads to rapid development of the TTP-deficiency syndrome in previously healthy $(-/-)$ mice, and that the syndrome can also be prevented by producing the TTP-deficiency state in mice deficient in both types of TNF $\alpha$ receptor (Carballo, E., and P.J. Blackshear, manuscript in preparation). Taken together, these data strongly support the proposition that excess effective circulating concentrations of TNF $\alpha$ are responsible for mediating most if not all of the clinical and pathological features of the syndrome.

How might simple marrow transplantation lead to this effective TNF $\alpha$ excess? One major possibility is that marrow stem cells or other progenitors form the basis for reconstitu-

\section{A TNF $\alpha$ mRNA}

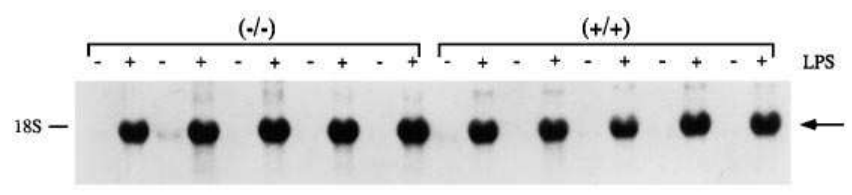

B TNF $\alpha$

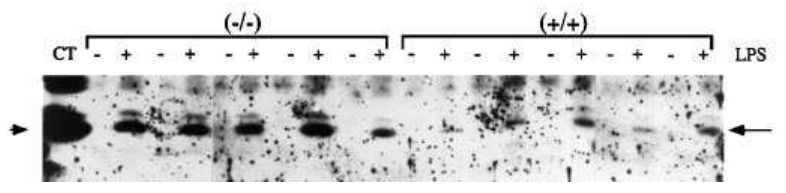

Figure 6. TNF $\alpha$ production and mRNA expression in bone marrowderived macrophages. $(A)$ Expression of TNF $\alpha$ mRNA. Bone marrow-derived macrophages were prepared from five adult TTP $(-/-)$ and five $(+/+)$ animals of 6-7 mo of age, as described in Methods, and incubated for $4 \mathrm{~h}$ in the presence or absence of $1 \mu \mathrm{g} / \mathrm{ml}$ LPS. Total RNA was obtained and analyzed by Northern blot with a mouse $\mathrm{TNF} \alpha \mathrm{cDNA}$. Note the modestly increased levels of TNF $\alpha$ mRNA in the (-/-) animals after LPS stimulation. (B) A volume of culture supernatant equivalent to $1.25 \times 10^{5}$ cells was analyzed by Western blot for accumulation of TNF $\alpha$, in the same cells used in $A$ and Fig. $7 A$. The arrow shows the position of TNF $\alpha$, and the arrowhead the position of the positive control TNF $\alpha$ produced by LPS-stimulated Raw 264.7 cells. 
tion of a cell population in the recipient that elaborates excess $\mathrm{TNF} \alpha$. A second possibility is that the reconstituted cell population could secrete cytokine(s) that would induce other cells in the recipients to produce TNF $\alpha$. Neither T nor B lymphocytes possessed this property; these cells appeared unlikely candidates in any case because their populations were quickly (within a few weeks) reconstituted in the recipients, whereas the clinical TTP-deficiency syndrome became apparent only after a lag period of several months. This is supported by previous studies on the role of T lymphocytes in disease transmission in mice: the lag periods between whole bone marrow or peripheral mononuclear cell transplantation and the appearance of clinical signs ranged from 2 to $8 \mathrm{wk}(38-41)$.

On the other hand, macrophages cultured from resident peritoneal cells, and derived from fetal liver and from bone marrow precursors, exhibited an apparently innate ability to overproduce TNF $\alpha$ when they were from TTP $(-/-)$ mice, compared to cells from their $(+/+)$ littermates. This was particularly impressive in the case of the fetal liver-derived cells, since these fetal mice had never been exposed to the chronic, systemic inflammatory state that characterizes the TTP-deficiency syndrome in the adult mouse. This genotype difference was also dramatic in the bone marrow-derived macrophages, which are generated after $10 \mathrm{~d}$ in culture, during which the precursors differentiate into macrophages. This preparation also avoids any influence attributable to the systemic inflammatory state present in the animals of origin. The fetal liver-derived macrophages from the $(-/-)$ embryos also secreted more TNF $\alpha$ per cell in the unstimulated state compared to cells from their $(+/+)$ littermates, as well as about five times more TNF $\alpha$ at each concentration of LPS used as a stimulus to TNF $\alpha$ pro-

\section{A TNF $\alpha$ mRNA levels}

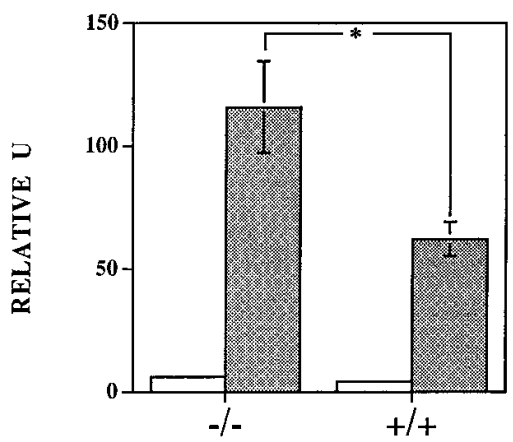

B TNF $\alpha$ levels

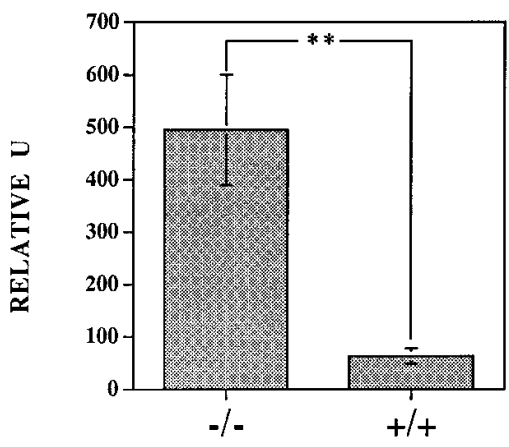

duction. These differences were similar to those seen in the bone marrow-derived macrophages, with increases in TNF $\alpha$ accumulation of approximately sevenfold after $4 \mathrm{~h}$ of LPS treatment. In both cases, the increase in medium TNF $\alpha$ accumulation was accompanied by an increased level of $\mathrm{TNF} \alpha$ mRNA in the $(-/-)$ cells.

These data suggest that cells of the macrophage/monocyte lineage may be among the cell types responsible for the excess effective TNF $\alpha$ levels seen in TTP-deficient mice. This could account for the relatively long lag period between marrow transplantation and the development of the TTP-deficiency syndrome; this time might be necessary to expand the macrophage/monocyte population to a clinically significant level from relatively few transplanted progenitors. There is limited information available in the literature about the lag period necessary for bone marrow-derived macrophage progenitors to repopulate the whole body. However, Krall et al. (42) reported a rapid repopulation of hematopoietic tissues with donor-derived cells (both myeloid and lymphoid) after bone marrow transplantation ( $2 \mathrm{wk}-1 \mathrm{mo}$ ), but only $30 \%$ of the macrophages were from donor origin after 6 mo.

Other potential pathophysiological possibilities are not supported by the data. For example, it was possible that an innate genetic change in myeloid progenitors might lead them to expand enormously in TTP $(-/-)$ mice and secondarily produce an excess of TNF $\alpha$. Several facts argue against this possibility. First, we have shown that TTP $(-/-)$ myeloid progenitors exhibit normal proliferative rates both in the absence and presence of a wide variety of hematopoietic growth factors (10). Second, previous animal models have demonstrated clearly that myeloid hyperplasia is a consequence of chronic $\mathrm{TNF} \alpha$ administration (17); our own studies showed that development of the myeloid hyperplasia in TTP-deficient mice could be prevented entirely by treatment with anti-TNF $\alpha$ mAbs (10). Finally, only a small percentage of the hyperplastic myeloid cells in recipients of the $(-/-)$ marrow was TTP $(-/-)$, as demonstrated by $\mathrm{Y}$ chromosome DNA in situ hybridization.

These studies show for the first time that macrophages derived from TTP-deficient fetal mice or adult bone marrow exhibit an apparent primary tendency to oversecrete TNF $\alpha$, thus implicating TTP in some aspect of TNF $\alpha$ biosynthesis and/or release in this cell type. Ongoing experiments are attempting to identify the locus of this effect in the TNF $\alpha$ biosynthetic pathway, and ultimately to identify how the affected locus is influenced by TTP under normal circumstances. However, the mechanism by which TTP deficiency in macrophages leads to an increase in TNF $\alpha$ production by these cells cannot be determined from these data. TNF $\alpha$ production by macrophages is stimulated by LPS at many levels, including transcription, mRNA stability, and mRNA translation $(43,44)$; other potential steps in the secretory pathway may also be involved, such as cleavage of the TNF $\alpha$ precursor to yield the mature secreted product $(45,46)$. In addition, there are reports that $\mathrm{TNF} \alpha$ can promote its own formation in macrophages, raising the possibility of a positive feedback loop in these experiments. This possibility can be investigated in future studies involving macrophages deficient in both TTP and TNF $\alpha$ receptor(s). Despite these uncertainties, the modest but reproducible increase in TNF $\alpha$ mRNA levels seen in TTP $(-/-)$ mice suggests that the mechanism by which TTP normally inhibits $\mathrm{TNF} \alpha$ production will involve early steps in the TNF $\alpha$ biosyn- 
thetic pathway, e.g., transcription or mRNA stability. Careful optimization of this mRNA effect, using various stimulation times as well as different concentrations and types of secretagogues, may ultimately permit the molecular elucidation of the TTP-TNF $\alpha$ interaction.

There are few human diseases directly related to macrophage malfunction, but patients with chronic myeloproliferative disorders exhibit increased levels of macrophage colony stimulating factor (M-CSF) (47). Those authors suggest that M-CSF might have an autocrine effect on the cells of the monocytic/macrophagic lineage that results in increased production of this cytokine. In another study, Kaushansky et al. (48) showed that TNF $\alpha$ treatment of mice induces the synthesis of M-CSF, GM-CSF, and IL-1, and also suggested that macrophages themselves might be responsible for the greater production of M-CSF. These data suggest that macrophages from TTP-deficient mice are exposed to an autocrine loop that leads to excess $\mathrm{TNF} \alpha$ production. In the experiments described in this paper, we performed transplantation of whole bone marrow, including stromal cells, necessary for the normal development of the hematopoietic system (49). Preliminary data from our laboratory suggest that embryonic fibroblasts do not overproduce TNF $\alpha$ (our unpublished data), but it is possible that a population of stromal cells (fibroblasts or epithelial cells) might be responsible for the production of a cytokine that could activate or stimulate the growth of otherwise normal macrophages.

Finally, gene transfer into hematopoietic cells and gene therapy have proven to be successful in the treatment of macrophage-related diseases in mice, such as Gaucher's disease (50). Recent technical developments have allowed similar treatments to be attempted in humans (51). It is possible that the identification of TTP as an apparent inhibitor of macrophage $\mathrm{TNF} \alpha$ production may provide new insights into the development of treatments for human diseases related to increased $\mathrm{TNF} \alpha$ production.

\section{Acknowledgments}

We are very grateful to Dr. R.J. Rahija and Dr. T.F. Tedder for RAG2 $(-/-)$ mice, to Dr. J.B. Weinberg and M.A. Misukonis for their help in obtaining peritoneal macrophages, to Dr. W.S. Lai for the TTP probe, to Dr. C.E. Bishop for the Y chromosome probe, to Dr. T.F. Tedder and Dr. S. Sato for $\mathrm{mAbs}$ against TCR and CD3, to Dr. F.C. Kull for anti-TNF $\alpha$ antibody, and to J.S. Tuttle for her help in processing the histological samples.

G.S. Gilkeson was supported by the Veterans' Administration Medical Research Service, and by grants from the Arthritis Foundation and the Lupus Foundation. E. Carballo is supported by a Spanish Ministry of Education and Culture Fulbright Scholarship. P.J. Blackshear is an Investigator of the Howard Hughes Medical Institute.

\section{References}

1. Lai, W.S., D.J. Stumpo, and P.J. Blackshear. 1990. Rapid insulin-stimulated accumulation of an mRNA encoding a proline-rich protein. J. Biol. Chem. 265:16556-16563.

2. Varnum, B.C., R.W. Lim, V.P. Sukhatme, and H.R. Herschman. 1989. Nucleotide sequence of a cDNA encoding TIS11, a message induced in Swiss 3T3 cells by the tumor promoter tetradecanoyl phorbol acetate. Oncogene. 4: 119-120.

3. DuBois, R.N., N.W. McLane, K. Ryder, L.F. Lau, and D.A. Nathans. 1990. Growth factor-inducible nuclear protein with a novel cysteine/histidine repetitive sequence. J. Biol. Chem. 265:19185-19191.

4. Heximer, S.P., and D.R. Forsdyke. 1993. A human putative lymphocyte
$\mathrm{G}_{0} / \mathrm{G}_{1}$ switch gene homologous to a rodent gene encoding a zinc-binding potential transcription factor. DNA Cell Biol. 12:73-88.

5. Varnum, B.C., Q. Ma, T. Chi, B. Fletcher, and H.R. Herschman. 1991. The TIS11 primary response gene is a member of a gene family that encodes proteins with a highly conserved sequence containing an unusual Cys-His repeat. Mol. Cell. Biol. 11:1754-1758.

6. Taylor, G.A., W.S. Lai, R.J. Oakey, M.F. Seldin, T.B. Shows, R.L. Eddy, Jr., and P.J. Blackshear. 1991. The human TTP protein: sequence, alignment with related proteins, and chromosomal localization of the mouse and human genes. Nucleic. Acids Res. 19:3454

7. Worthington, M.T., B.T. Amann, D. Nathans, and J.M. Berg. 1996. Metal binding properties and secondary structure of the zinc-binding domain of Nup475. Proc. Natl. Acad. Sci. USA. 93:13754-13759.

8. Taylor, G.A., M.J. Thompson, W.S. Lai, and P.J. Blackshear. 1995. Phosphorylation of tristetraprolin, a potential zinc finger transcription factor, by mitogen stimulation in intact cells and by mitogen activated protein kinase in vitro. J. Biol. Chem. 270:13341-13347.

9. Taylor, G.A., M.J. Thompson, W.S. Lai, and P.J. Blackshear. 1996. Mitogens stimulate the rapid nuclear to cytosolic translocation of tristetraprolin, a potential zinc-finger transcription factor. Mol. Endocrinol. 10:140-146.

10. Taylor, G.A., E. Carballo, D.M. Lee, W.S. Lai, M.J. Thompson, D.D. Patel, D.I. Schenkman, G.S. Gilkeson, H.E. Broxmeyer, B.F. Haynes, and P.J. Blackshear. 1996. A pathogenetic role for TNF $\alpha$ in the syndrome of cachexia, arthritis, and autoimmunity resulting from tristetraprolin (TTP) deficiency. Immunity. 4:445-454.

11. Rosenberg, A.E. 1994. Skeletal system and soft tissue tumors. In Robbins Pathologic Basis of Disease. 5th ed. R.S. Cotran, V. Kumar, and S.L. Robbins, editors. W.B. Saunders Co., Philadelphia. 1247-1255.

12. Theofilopoulos, A.N., and F.J. Dixon. 1985. Murine models of systemic lupus erythematosus. Adv. Immunol. 37:269-390.

13. Hoffman, R., and M.N. Silverstein. 1995. Agnogenic myeloid metaplasia. In Hematology. Basic Principles and Practice. 2nd ed. R. Hoffman, E.J. Benz, Jr., S.J. Shattil, B. Furie, H.J. Cohen, and L.E. Silverstein, editors Churchill-Livingstone, Inc., New York. 1160-1174.

14. Schwartz, R.S. 1993. Autoimmunity and autoimmune diseases. In Fundamental Immunology. 3rd ed. W.E. Paul, editor. Raven Press, New York. 1033-1097.

15. Keffer, J., L. Probert, H. Cazlaris, S. Georgopoulos, E. Kaslaris, D. Kioussis, and G. Kollias. 1991. Transgenic mice expressing tumor necrosis factor: a predictive genetic model of arthritis. EMBO (Eur. Mol. Biol. Organ.) J. 10:4025-4031.

16. Cheng, J., K. Tursken, Q.-C. Yu, H. Schreiber, and M. Teng. 1992. Cachexia and graft-vs.-host-disease-type skin changes in keratin promoterdriven TNF $\alpha$ transgenic mice. Genes Dev. 6:1444-1456.

17. Ulich, T.R., S.S. Shin, and J. del Castillo. 1993. Haematologic effects of TNF. Res. Immunol. 144:347-354.

18. Sheehan, K.C.F., N.H. Ruddle, and R.D. Schreiber. 1989. Generation and characterization of hamster monoclonal antibodies that neutralize murine tumor necrosis factors. J. Immunol. 142:3884-3893.

19. Mombaerts, P., J. Iacomini, R.S. Johnson, K. Herrup, S. Tonegawa, and V.E. Papaioannou. 1992. RAG-1-deficient mice have no mature B and T lymphocytes. Cell. 68:869-877.

20. Shinkai, Y., G. Rathbun, K.P. Lam, E.M. Oltz, V. Stewart, M. Mendelsohn, J. Charron, M. Datta, A.M. Stall, and F.W. Alt. 1992. RAG-2 (-/-) mice lack mature lymphocytes owing to inability to initiate $\mathrm{V}(\mathrm{D}) \mathrm{J}$ rearrangement. Cell. 68:855-867.

21. Schuler, W., I.J. Weiler, A. Schuler, R.A. Phillips, N. Rosenberg, T.W. Mak, J.F. Kearney, R.P. Perry, and M.J. Bosma. 1986. Rearrangement of antigen receptor genes is defective in mice with severe combined immune deficiency. Cell. 46:963-972.

22. Stumpo, D.J., J.M. Graff, K.A. Albert, P. Greengard, and P.J. Blackshear. 1989. Molecular cloning, characterization and expression of a cDNA encoding the 80 to $87 \mathrm{kDa}$ myristoylated alanine-rich $\mathrm{C}$ kinase substrate: a major cellular substrate for protein kinase C. Proc. Natl. Acad. Sci. USA. 86:40124016.

23. Lai, W.S., M.J. Thompson, G.A. Taylor, Y. Liu, and P.J. Blackshear 1995. Promoter analysis of Zfp-36, the mitogen-inducible gene encoding the zinc finger protein tristetraprolin. J. Biol. Chem. 270:25266-25272.

24. Linton, M.F., J.B. Atkinson, and S. Fazio. 1995. Prevention of atherosclerosis in apolipoprotein E-deficient mice by bone marrow transplantation. Science (Wash. DC). 267:1034-1037.

25. Bishop, C.E., and D. Hatat. 1987. Molecular cloning and sequence analysis of a mouse Y chromosome RNA transcript expressed in the testis. Nucleic. Acids Res. 15:2959-2969.

26. Keighren, M., and J.D. West. 1993. Analysis of cell ploidy in histological sections of mouse tissues by DNA-DNA in situ hybridization with digoxigenin labelled probes. Histochem. J. 25:30-44.

27. Ding, A., S.D. Wright, and C. Nathan. 1987. Activation of mouse peritoneal macrophages by monoclonal antibodies to Mac-1 (complement receptor type 3). J. Exp. Med. 165:733-749.

28. Tucker, S.B., R.V. Pierre, and R.E. Jordon. 1977. Rapid identification of monocytes in a mixed mononuclear cell preparation. J. Immunol. Methods 14: 
267-269

29. Warren, M.K., and S.N. Vogel. 1985. Bone marrow-derived macrophages: development and regulation of differentiation markers by colony-stimulating factor and interferons. J. Immunol. 134:982-989.

30. Hume, D.A., and S. Gordon. 1983. Optimal conditions for proliferation of bone marrow-derived mouse macrophages in culture: the roles of CSF-1, serum, $\mathrm{Ca}^{2+}$, and adherence. J. Cell. Physiol. 117:189-194.

31. Kruisbeek, A.M. 1995. In vitro assays for mouse lymphocyte function. In Current Protocols in Immunology. J.E. Coligan, A.M. Kruisbeek, D.H. Margulies, E.M. Shevach, and W. Strober, editors. John Wiley \& Sons Inc., New York.

32. Sato, S., D.A. Steeber, and T.F. Tedder. 1995. The CD19 signal transduction molecule is a response regulator of B-lymphocyte differentiation. Proc. Natl. Acad. Sci. USA. 92:11558-11562.

33. Nishimura, Y., M. Eto, T. Maeda, K. Hiromatsu, N. Kobayashi, K. Nomoto, Y.Y. Kong, and K. Nomoto. 1994. Inhibition of skin xenograft rejection by depleting T-cell receptor $\alpha \beta$-bearing cells without T-cell receptor $\gamma \delta$-bearing cells or natural killer cells by monoclonal antibody. Immunology. 83:196-204.

34. Blackshear, P.J. 1984. Systems for polyacrylamide gel electrophoresis. Methods Enzymol. 104:237-255.

35. Kull, F.C., Jr., and J.M. Besterman. 1990. Drug-induced alterations of tumor necrosis factor-mediated cytotoxicity: discrimination of early versus late stage action. J. Cell. Biochem. 42:1-12.

36. Chomczynski, P. 1993. A reagent for the single-step simultaneous isolation of RNA, DNA and proteins from cell and tissue samples. Biotechniques. 15:532-537.

37. Tso, J.Y., X.H. Sun, T.H. Kao, K.S. Reece, and R. Wu. 1985. Isolation and characterization of rat and human glyceraldehyde-3-phosphate dehydrogenase cDNAs: genomic complexity and molecular evolution of the gene. Nucleic Acids Res. 13:2485-2502.

38. Krams, S.M., K. Dorshkind, and M.E. Gershwin. 1989. Generation of biliary lesions after transfer of human lymphocytes into severe combined immunodeficient (SCID) mice. J. Exp. Med. 170:1919-1930.

39. Haskins, K., M. Portas, B. Bergman, K. Lafferty, and B. Bradley. 1989. Pancreatic islet-specific T-cell clones from nonobese diabetic mice. Proc. Natl. Acad. Sci. USA. 86:8000-8004.

40. Ashany, A., J. Hines, A. Gharavi, J. Mouradian, and K.B. Elkon. 1992. Analysis of autoantibody production in SCID-systemic lupus erythematosus (SLE) chimeras. Clin. Exp. Immunol. 88:84-90.
41. Duchosal, M.A., P.J. McConahey, C.A. Robinson, and F.J. Dixon. 1990. Transfer of human systemic lupus erythematosus in severe combined immunodeficient (SCID) mice. J. Exp. Med. 172:985-988.

42. Krall, W.J., P.M. Challita, L.S. Perlmutter, D.C. Skelton, and D.B. Koln. 1994. Cells expressing human glucocerebrosidase from a retroviral vector repopulate macrophages and central nervous system microglia after murine bone marrow transplantation. Blood. 83:2737-2748.

43. Han, J., T. Brown, and B. Beutler. 1990. Endotoxin-responsive sequences control cachectin/tumor necrosis factor biosynthesis at the translational level. J. Exp. Med. 171:465-475.

44. Kruys, V., K. Kemmer, A. Shakhov, V. Jongeneel, and B. Beutler. 1992 Constitutive activity of the tumor necrosis factor promoter is canceled by the 3 untranslated region in nonmacrophage cell lines; a trans-dominant factor overcomes this suppressive effect. Proc. Natl. Acad. Sci. USA. 89:673-677.

45. Gearing, A.J.H., P. Beckett, M. Christodoulou, M. Churchill, J. Clements, A.H. Davidson, A.H. Drummond, W.A. Galloway, R. Gilbert, J.L. Gordon, et al. 1994. Processing of tumor necrosis factor- $\alpha$ precursor by metalloproteinases. Nature (Lond.). 370:555-557.

46. McGeehan, G.M., J.D. Becherer, R.C. Bast, Jr., C.M. Boyer, B. Champion, K.M. Connolly, J.G. Conway, P. Furdon, S. Karp, S. Kidao, et al. 1994 Regulation of tumor necrosis factor- $\alpha$ processing by a metalloproteinase inhibitor. Nature (Lond.). 370:558-561.

47. Gilbert, H.S., V. Praloran, and E.R. Stanley. 1989. Increased circulating CSF-1 (M-CSF) in myeloproliferative disease: association with myeloid metaplasia and peripheral bone marrow extension. Blood. 74:1231-1234.

48. Kaushansky, K., V.C. Broudy, J.M. Harlan, and J.W. Adamson. 1988. Tumor necrosis factor- $\alpha$ and tumor necrosis factor- $\beta$ (lymphotoxin) stimulate the production of granulocyte-macrophage colony-stimulating factor, macrophage colony-stimulating factor, and IL-1 in vivo. J. Immunol. 141:3410-3415.

49. Dexter, T.M., T.D. Allen, and L.G. Lajtha. 1977. Conditions controlling the proliferation of haemopoietic stem cells in vitro. J. Cell. Physiol. 91:335344

50. Karlsson, S., P.H. Correll, and L. Xu. 1993. Gene transfer and bone marrow transplantation with special reference to Gaucher's disease. Bone Marrow Transplant. 11 (Suppl. 1):124-127.

51. Freas-Lutz, D.L., P.H. Correll, S.F. Dougherty, L. Xu, D.H. Pluznik, and S. Karlsson. 1994. Expression of human glucocerebrosidase in murine macrophages: identification of efficient retroviral vectors. Exp. Hematol. (Charlottesv.). 22:857-865. 